\begin{tabular}{|} 
Ambiente \& Água - An Interdisciplinary Journal of Applied Science \\
ISSN 1980-993X - doi:10.4136/1980-993X \\
www.ambi-agua.net \\
E-mail: ambi.agua@gmail.com
\end{tabular}

\title{
Distribution of physical and chemical variables in the water column and characterization of the bottom sediment in a macrotidal estuary on the Amazon coast of the state of Maranhão, Brazil
}

\author{
ARTICLES doi:10.4136/ambi-agua.2798
}

Received: 24 Sep. 2021; Accepted: 11 Jan. 2022

\author{
Adilson Matheus Borges Machado ${ }^{1,2 *}$; ; Samara Aranha Eschrique ${ }^{3}$ iD; \\ Leonardo Gonçalves de Lima ${ }^{3}$; Claudia Klose Parise ${ }^{1,4}$; \\ Leonardo Silva Soares ${ }^{3,5}$; James Werllen Jesus Azevedo ${ }^{3,6}$; \\ Marcelo Henrique Lopes Silva ${ }^{3}$; Antonio Carlos Leal de Castro ${ }^{3,5}$ (iD
}

\begin{abstract}
${ }^{1}$ Departamento de Oceanografia e Limnologia. Universidade Federal do Maranhão (UFMA), Avenida dos Portugueses, n 1966, CEP: 65080-805, São Luís, Maranhão, Brazil. E-mail: claudiakparise@gmail.com ${ }^{2}$ Doutorando do Programa de Pós-graduação em Desenvolvimento e Meio Ambiente. Universidade Federal do Ceará (UFC), Centro de Ciências, Bloco 902, Campus do Pici, CEP: 60455-970, Fortaleza, Ceará, Brazil.

${ }^{3}$ Programa de Pós-graduação em Desenvolvimento e Meio Ambiente. Departamento de Oceanografia e Limnologia. Universidade Federal do Maranhão (UFMA), Avenida dos Portugueses, $\mathrm{n}^{\circ} 1966$,

CEP: 65080-805, São Luís, Maranhão, Brazil. E-mail: samara.eschrique@ufma.br, paleonardo_7@hotmail.com, leonardo.soares@ufma.br, james.werllen@ufma.br,marcelo.silva@ufma.br,alec@ufma.br

${ }^{4}$ Laboratório de Estudos e Modelagem Climática. Universidade Federal do Maranhão (UFMA), Avenida dos

Portugueses, n 1966, CEP: 65080-805, São Luís, Maranhão, Brazil. E-mail: claudiakparise@ gmail.com

${ }^{5}$ Programa de Pós-graduação em Saúde e Ambiente. Universidade Federal do Maranhão (UFMA), Avenida dos

Portugueses, n 1966, CEP: 65080-805, São Luís, Maranhão, Brazil. E-mail: leonardo.soares@ufma.br, alec@ufma.br

${ }^{6}$ Coordenação de Engenharia de Pesca. Universidade Federal do Maranhão (UFMA), Estrada de Pacas, KM 10, CEP: 65200-000, Pinheiro, Maranhão, Brazil. E-mail: james.werllen@ufma.br

*Corresponding author. E-mail: adilsonborges94@gmail.com
\end{abstract}

\begin{abstract}
The objective of this research was to characterize the distribution of dissolved nutrients at six sampling stations in the estuary of the Anil River (ARE) and characterize the bottom sediment. The study area is influenced by a tropical climate and semidiurnal macrotidal regime. Sampling of the surface water and sediment was performed in the main channel at six sampling stations distributed along the estuary in the rainy period (May 9th) and dry period (October 5th) during the spring. Physical variables were collected with the aid of a HANNA HI-8424 multiparameter probe (water temperature, salinity, $\mathrm{pH}$, dissolved oxygen, and turbidity) and YSI CTD (conductivity, temperature, and depth) probe. A van Veen dredge was used for the collection of bottom sediment from the main channel. The sedimentological results were heterogeneous. Grain size ranged from very fine to medium sand. Dissolved nutrients in the ARE had different sources depending on the season. Continental and fluvial inputs, evidenced by salinity values, governed the distribution of nutrients in the rainy period (January to June), whereas nutrient concentrations were related to the recycling of organic material in the estuary in the dry season (July to December). The considerable presence of sand in the main channel indicates that the sediments available in ARE are exposed to intense hydrodynamics. The distribution of nutrients and the grain size revealed the occurrence of different sources in the estuary according to the rainfall regime and the intense hydrodynamics of tidal currents (semidiurnal macrotidal).
\end{abstract}

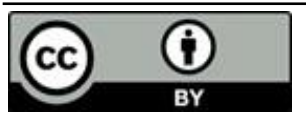

This is an Open Access article distributed under the terms of the Creative Commons Attribution License, which permits unrestricted use, distribution, and reproduction in any medium, provided the original work is properly cited. 
Keywords: dissolved nutrients, estuarine environment, sedimentology.

\section{Distribuição das variáveis físicas e químicas na coluna d'água e caracterização do sedimento de fundo em um estuário de macromaré da costa amazônica do estado do Maranhão, Brasil}

\section{RESUMO}

O objetivo desta pesquisa foi caracterizar a distribuição dos nutrientes dissolvidos em seis estações de amostragem no estuário do rio Anil (ERA) e caracterizar o sedimento de fundo. A área de estudo é influenciada por um clima tropical e regime macromarés semidiurnas. A amostragem das águas superficiais e sedimentos foi realizada no canal principal em seis estações de amostragem distribuídas ao longo do estuário no período chuvoso (09 de maio) e seco (05 de outubro) durante a primavera. Variáveis físicas foram coletadas com o auxílio de uma sonda multiparâmetro HANNA HI-8424 (temperatura da água, salinidade, pH, oxigênio dissolvido e turbidez) e sonda YSI CTD (condutividade, temperatura e profundidade). Uma draga van Veen foi usada para a coleta de sedimentos de fundo do canal principal. Os resultados sedimentológicos foram heterogêneos. $\mathrm{O}$ tamanho do grão variou de areia muito fina a média. Os nutrientes dissolvidos no ERA tinham fontes diferentes dependendo do período sazonal. Insumos continentais e fluviais, evidenciados pelos valores de salinidade, governaram a distribuição dos nutrientes no período chuvoso (janeiro a junho), enquanto as concentrações dos nutrientes foram relacionadas à reciclagem da matéria orgânica no estuário na estação seca (julho a dezembro). A presença de areia no canal principal indica que os sedimentos disponíveis no ERA estão expostos a uma hidrodinâmica intensa. A distribuição dos nutrientes e o tamanho do grão revelaram a ocorrência de diferentes fontes no estuário de acordo com o regime de chuvas e a intensa hidrodinâmica das correntes de maré (macromarés semidiurnas).

Palavras-chave: ambiente estuarino, nutrientes dissolvidos, sedimentologia.

\section{INTRODUCTION}

The northern coastal zone of Brazil is home to a combination of high-generation ecosystems of considerable environmental importance, the diversity of which is characterized by the transition between terrestrial and marine environments. The region between the states of Pará (PA) and Maranhão (MA) has one of the largest contiguous areas of mangroves in the world (700,000 ha) (Asp et al., 2018). The presence of mangroves exerts a direct influence on the dynamics of sediments in estuaries and the coastal zone (Mazda et al., 1995; McLachlan et al., 2020).

Estuaries are transition regions between rivers and the ocean characterized by gradients of salinity and density associated with the turbulent mixture of river water and seawater (Pritchard, 1955). The origin and evolution of most modern estuaries are related to the last marine transgression, which flooded extensions of river valleys carved during the last glacial stage, enabling the development of a broad accommodation space behind the coastline (Dalrymple, 1992).

Estuaries retain matter and particles originating from the continent to the adjacent marine environment, such as dissolved nutrients, which originate mainly from sedimentary rock. The continent is the main source of these elements in estuarine environments (Barcellos et al. 2012; Wolanski and Elliott, 2015).

Water quality in estuaries is evaluated mainly through measurements of dissolved oxygen, salinity, turbidity, temperature, and nutrient status (Onabule et al., 2020). Urban wastewaters and other byproducts lead to an increase in nutrient content, causing serious environmental, 
biological, and socioeconomic impacts on water systems and local populations (Esteves, 2011).

Coastal and estuarine sediments are transported by rivers to other water bodies or the adjacent ocean. The distribution of these sediments at a given point is important to the monitoring of possible sources of contamination. The behavior of the mud fraction of sediment is nearly always associated with substances that aggregate together, such as organic matter, as well as diffuse urban and agricultural inputs (Veronez et al., 2009). Estuarine systems may undergo a reduction in depth in response to three depositional processes: the entrance of sand and other marine sediments, the increase in sand deltas at the mouth of the river, and the aggregation of mud throughout the entire central portion of the estuary.

The Anil River Estuary (ARE) is located in a largely urban area (65.2\% of the sub-basin) and has a population of 250 thousand residents along its drainage basin, of the metropolitan region of São Luís, capital of the state of Maranhão, Brazil. The ARE is characterized by deforestation and the filling of mangroves for the construction of shanties as well as the discharge of domestic and hospital waste (Santos et al., 2019). Studies aimed at understanding the dynamics of physical, chemical, and sedimentary variables make an important contribution to knowledge on estuarine systems and variations in these systems in terms of the distribution of sedimentary and physical characteristics (Serejo et al., 2020).

Serra et al. (2003) analyzed physical and chemical variables and nutrient concentrations in the ARE and demonstrated a critical situation in terms of the environmental and sanitary aspects of the estuary through microbiological evaluations and environmental variables. Martins and Lopes (2009) demonstrated the existence of the discharge of wastewaters from a medication industry in the proximities of the ARE as well as the occurrence of a hospital that discharges its effluents into the estuary without prior treatment, stressing that such irregularities constitute a risk to the river population that consumes fishes and crustaceans collected from the estuarine environment.

As estuaries serve as sources of matter and particles for the adjacent ocean, sediments, with the influence of biogeochemical cycles, are the main lodging compartment of these materials of a terrestrial origin, such as dissolved nutrients. Therefore, the aim of this work was to better understand the distribution of physical and chemical variables and dissolved nutrients in the water column as well as to characterize the bottom sediment and its concentrations of organic matter in a macrotidal estuary in the equatorial region of the Brazilian Amazon.

\section{MATERIAL AND METHODS}

\subsection{Study Area}

The study area was the Anil River Estuary (ARE), which is located in the northwestern quadrant of São Luís Island in the central portion of the Maranhão Gulf composed of the municipalities of Paço do Luminar, São Luís, São José de Ribamar, and Raposa. The drainage basin of the Anil River has an area of $40.77 \mathrm{~km}^{2}$, perimeter of $33.39 \mathrm{~km}$, and length of 13.08 km (Alcântara, 2004; Cruz et al., 2020).

Records in the literature describe a dynamic estuarine environment, with circulation determined mainly by the semidiurnal macrotidal regime, with the occurrence of two low tides and two high tides per day, with an average of $6.6 \mathrm{~m}$ at high tide, reaching approximately 7.0 $\mathrm{m}$ in height during equinoctial tides. The tidal current reaches $2.5 \mathrm{~m} \mathrm{~s}^{-1}$ and wave heights are between 0.6 and $1.4 \mathrm{~m}$ (El-Robrini et al., 2006). Feitosa (1989) calculated that the river has an outflow of approximately $15 \mathrm{~m}^{3} \mathrm{~s}^{-1}$ in the rainy period and $1 \mathrm{~m}^{3} \mathrm{~s}^{-1}$ in the dry period.

Mean annual precipitation in the drainage basin is on the order of $1900 \mathrm{~mm}$ and the region is marked by two distinct, non-homogenous periods: a rainy period from January to June and a dry period from July to December, both of which are influenced by the position of the Intertropical Convergence Zone. Mean annual temperatures are typical of equatorial regions and range from 26 to $29^{\circ} \mathrm{C}$ (INMET, 2020). 
Geomorphologically, the Anil River Basin is part of the fluvial-marine plain of the Maranhão Gulf. Stratigraphically, the basin has sequences of the Itapecuru Formation (formed during the Cretaceous), subdivided into the Psammitic Lower Member and Alcântara Upper Member, composed generally of sandstone, mudstone, shale, and limestone. The sediment is composed of clay, silt, very fine sand, and limestone (Corrêa-Martins, 2019).

\subsection{Water sampling and analysis}

Sampling of the surface water and sediment was performed in the main channel at six sampling stations distributed along the estuary (Figure 1) in the rainy period (May 9th) and dry period (October 5th) during the spring tide cycle in flood tide.

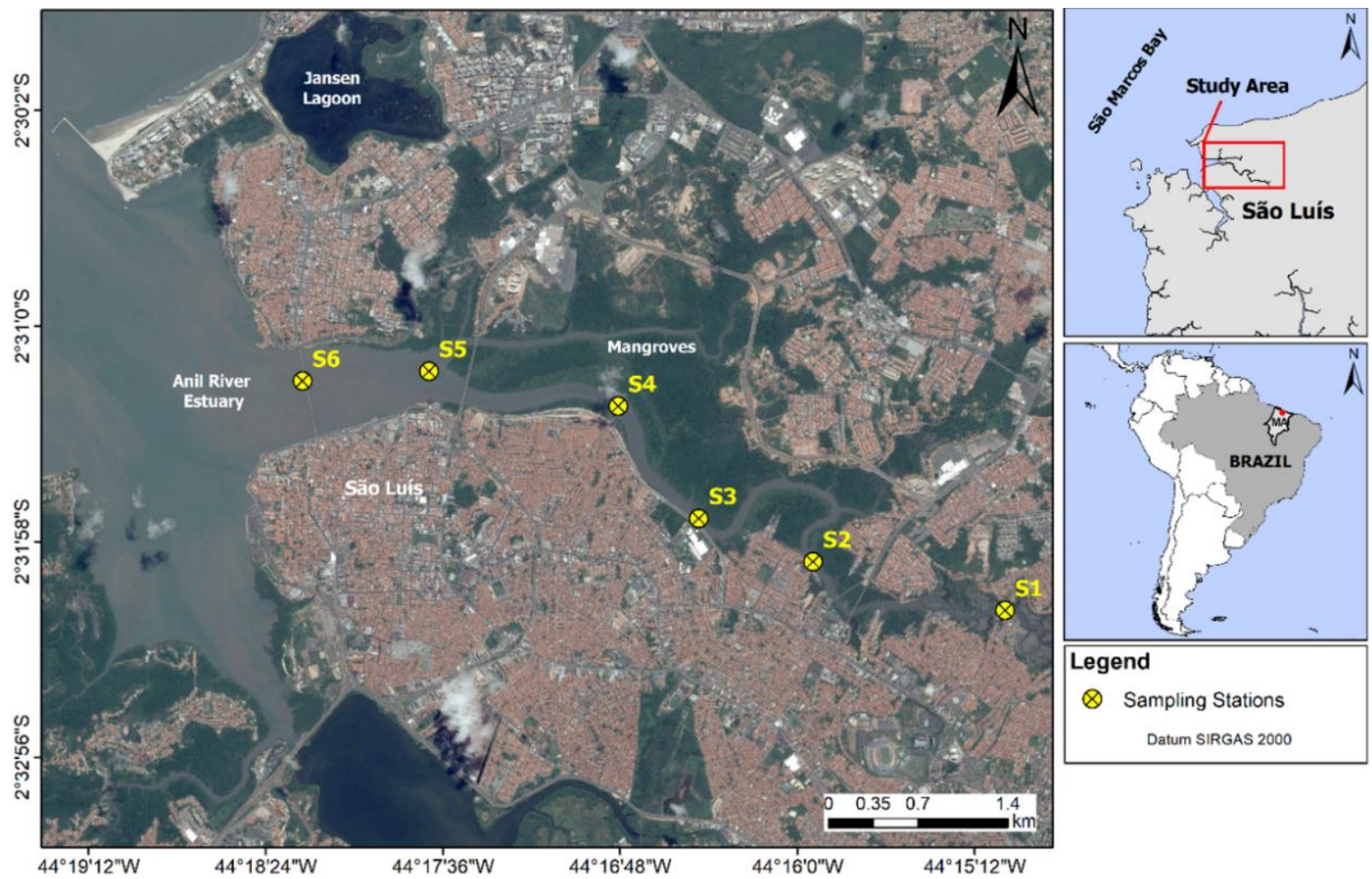

Figure 1. Location of sampling stations (S1 to S6) in Anil River Estuary. Source: Google Earth Pro and IBGE.

Rainfall data for the city of São Luís were obtained from the historical databank of the Instituto Nacional de Meteorologia (INMET [National Meteorology Institute]). In the field, data on the water depth, temperature, and salinity were determined using a CTD (conductivity, temperature, and depth) device (YSI CastAway ${ }^{\circledR}$ ) for salinity the resolution is 0.01 , accuracy of \pm 0.01 and for the temperature the resolution is $0.01^{\circ} \mathrm{C}$ and \pm 0.05 accuracy. Salinity was converted into $\mathrm{g} \mathrm{kg}^{-1}$ in accordance with the 2010 International Thermodynamic Equation of Seawater - TEOS 10 (http://www.teos10.org/).

Water transparency was measured with the aid of a Secchi disc using the light extinction coefficient suggested by Poole and Atkins (1929) (Equation 1):

$$
\begin{gathered}
\mathrm{k}=1.7 \cdot \mathrm{d}^{-1} \\
\mathrm{Z}_{\mathrm{eu}}=4 \cdot 7 \cdot \mathrm{K}^{-1}
\end{gathered}
$$

In which $\mathrm{k}$ is the light extinction coefficient, $\mathrm{d}$ is the depth of disappearance of the Secchi disc in meters, and $\mathrm{Z}_{\mathrm{eu}}$ is the depth of the layer of up to $1 \%$ of incident light, which corresponds to the water transparency value. 
The potential of hydrogen $(\mathrm{pH})$ was measured using the HANNA HI-8424 probe, which was previously calibrated with solutions of $\mathrm{pH} 4,7$, and 10 , accuracy of \pm 0.01 and range -2.00 to 16.00 . In the laboratory, turbidity was measured using a previously calibrated HACH model DR/2000 spectrophotometer with an accuracy of $\pm 2 \%$, detection limit of 1 . Dissolved oxygen (DO) was determined based on the Winkler method (1888), as described in Strickland and Parsons (1972). The saturation percentage of dissolved oxygen (\%DO) was calculated using the table proposed by Aminot and Chaussepied (1983).

Total suspended solids (TSS) were determined by gravimetry using the methods recommended by Strickland and Parsons (1972) and (APHA et al., 2012). Suspended organic matter (OM) was determined using the filter combustion method according to (APHA et al., 2012). Dissolved nutrients, phosphate, and silicate were determined using the colorimetric method described in Strickland and Parsons (1972) and (Grasshoff et al., 1983) with the spectrophotometer (CARY 300 Conc UV-Visible Spectrophotometer, Agilent Technologies, California, USA). These methods have precision of $\pm 0.01 \mu \mathrm{mol} \mathrm{L} \mathrm{L}^{-1}$ for phosphate and \pm 0.1 $\mu \mathrm{mol} \mathrm{L}{ }^{-1}$ for silicate, the samples were filtered through $0.45 \mu \mathrm{m}$ Millipore cellulose acetate filters. The data were normalized and submitted to multivariate analysis using principal component analysis (PCA) to determine correlations between variables in each sampling campaign.

The QGIS 3.10.10 LTR program was used for the interpolation and mapping of the data. Interpolation is a procedure by which the values of the cells at the measured sites can be predicted with the aid of the surrounding cells (Childs, 2004). The interpolation method employed was Inverse Distance Weighting (IDW) (Watson and Philip, 1985; Childs, 2004; Gobler et al., 2019).

\subsection{Surficial sedimentology}

Bottom sediment samples from the main channel were collected using a van Veen grab sampler. The grain size distribution was analyzed by sifting (sand fraction) and sedimentation in columns based on Stokes' law (mud fraction). Preprocessing of the samples included the removal of salt by washing with freshwater. Granulometric analyses were performed following the method described by Folk and Ward (1957), using the sifting and pipetting technique. Total organic matter (OM) in the sediment was determined following the method described by Wetzel (1975) based on the difference in dry weight.

The SysGran 3.0 program (De Camargo, 2006) was used for the processing of the granulometric data following the method described by Folk and Ward (1957). The parameters considered in the statistical analyses were mean, median, selection (standard deviation), asymmetry, and kurtosis as well as the classification according to (Wentworth, 1922). The Pejrup diagram (Pejrup, 1988) was used to classify sediments according to hydrodynamic conditions.

\section{RESULTS AND DISCUSSION}

\subsection{Climate conditions}

Monthly rainfall ( $\mathrm{mm}$ ) was lower than the historical average during the collections in May (Rainy season) and October (Dry season) of 2016 (Figure 2a and b).

The Intertropical Convergence Zone (ITCZ) is a large-scale tropical system and the main determinant of rains in northern Brazil, especially in the first semester of the year (Molion, 1987). Climatic events such as El Niño and La Niña produce anomalous convections and high levels of divergence, causing anomalies in sea surface temperature in the equatorial Atlantic Ocean, which consequently cause significant rainfall anomalies in the northeastern region of Brazil (Pezzi and Cavalcanti, 2001; Andreoli and Kayano, 2006). The rainfall regime in northeastern Brazil is also influenced by the Atlantic Meridional Mode, Intertropical 
Convergence Zone, and high-level cyclones cyclonic vortices (Nobre and Shukla, 1996; Coutinho et al., 2010).
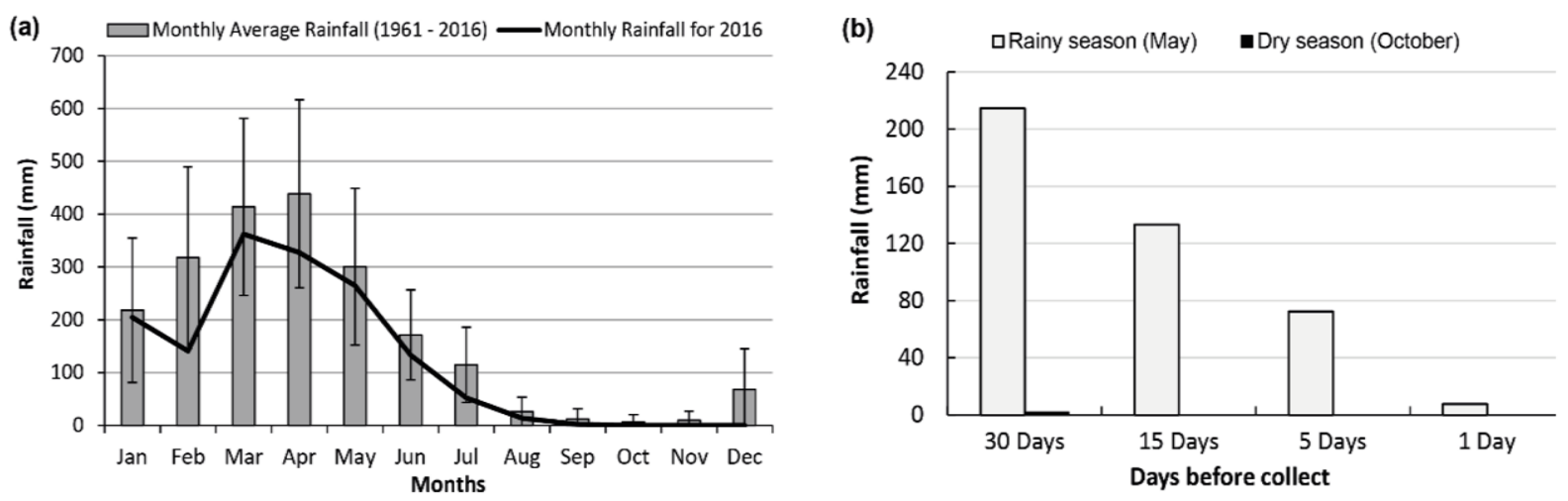

Figure 2. Rainfall in São Luís - MA. (a) Comparison of historical average rainfall (mm) from 1961 to 2016; (b) Rainfall days prior to sampling campaigns in Anil River Estuary (ARE).

\subsection{Physical and chemical characterization}

The hydrological and hydro chemical variables of the water surface of the ARE in the rainy period (May 2016) and dry period (October 2016) are displayed in Table 1 as well as Figures 3 (a-d), 4 (a-f), and 5 (a-f).

The depth stations in the ARE ranged spatially from 1.16 to $5.85 \mathrm{~m}$ during the rainy period and 2.19 and $6.66 \mathrm{~m}$ during the dry period. Water transparency ranged from 0.19 to $1.41 \mathrm{~m}$ in the rainy period and 0.68 to $1.60 \mathrm{~m}$ in the dry period. Surface temperature ranged from 28.41 to $29.87^{\circ} \mathrm{C}$ in the rainy period and 28.17 to $28.91^{\circ} \mathrm{C}$ in the dry period (Table 1 and Figure 3a). Salinity ranged from 3.94 to $29.17 \mathrm{~g} \mathrm{~kg}^{-1}$ in the rainy period and 18.33 to $34.37 \mathrm{~g} \mathrm{~kg}^{-1}$ in the dry period (Table 1; Figures $4 \mathrm{a}$ and $5 \mathrm{a}$ ). Conductivity at the surface of the estuary ranged from 7.64 to $49.29 \mathrm{mS} \mathrm{cm}^{-1}$ in the rainy period and 31.80 to $55.40 \mathrm{mS} \mathrm{cm} \mathrm{cm}^{-1}$ in the dry period (Table 1; Figure $3 \mathrm{~b}$ ). The $\mathrm{pH}$ ranged from 7.98 to 8.35 in the rainy period and 7.85 to 8.22 in the dry period (Table 1; Figure 3c).

Dissolved oxygen (DO) exhibited a gradient from the upper zone of the river to the mouth of the estuary, with differences among the sampling stations, ranging from 1.53 to $4.67 \mathrm{mg} \mathrm{L}^{-1}$ in the rainy period and 0.49 to $4.93 \mathrm{mg} \mathrm{L}^{-1}$ in the dry period (Table 1; Figures $4 \mathrm{~b}$ and $5 \mathrm{~b}$ ). Dissolved oxygen saturation (\%DO) ranged from 29 to $103 \%$ in the rainy period and 10 to $109 \%$ in the dry period (Table 1). Turbidity ranged from 18 to 65 NTU in the rainy period and 19 to 93 NTU in the dry period (Table 1; Figure 3d). Concentrations of total suspended solids (TSS) ranged from 54.33 to $123.33 \mathrm{mg} \mathrm{L}^{-1}$ in the rainy period and 46.00 to $156.67 \mathrm{mg} \mathrm{L}^{-1}$ in the dry period (Table 1; Figures $4 \mathrm{c}$ and $5 \mathrm{c}$ ).

The concentration of suspended Organic Matter (OM) ranged spatially from 16.67 to 30.50 $\mathrm{mg} \mathrm{L}^{-1}$ in the rainy period and 15.00 to $43.00 \mathrm{mg} \mathrm{L}^{-1}$ in the dry period (Table 1; Figures $4 \mathrm{~d}$ and $5 \mathrm{~d})$. The percentage (\%) of suspended OM in TSS ranged from 20 to $52 \%$ in the rainy period and 27 to $52 \%$ in the dry period. Concentrations of suspended OM did not differ among sampling stations in the rainy period, whereas higher values were found upstream in the estuary in the dry period.

The concentration of silicate in the surface water ranged spatially from 10.58 to $14.34 \mu \mathrm{mol} \mathrm{L}^{-1}$ in the rainy period and 5.13 to $9.10 \mu \mathrm{mol} \mathrm{L}^{-1}$ in the dry period (Table 1; Figures $4 \mathrm{e}$ and $5 \mathrm{e}$ ). The concentration of dissolved inorganic phosphate ranged from 0.13 to $0.65 \mu \mathrm{mol}$ $\mathrm{L}^{-1}$ in the rainy period and 0.13 to $2.19 \mu \mathrm{mol} \mathrm{L}^{-1}$ in the dry period, with the highest value found at $\mathrm{S} 2$ in the dry period (Table 1; Figure $4 \mathrm{f}$ and $5 \mathrm{f}$ ). 
Table 1. Hydrological and hydro-chemical variables in Anil River Estuary.

\begin{tabular}{|c|c|c|c|c|c|c|c|c|c|c|c|c|}
\hline \multirow{2}{*}{$\begin{array}{c}\text { Period } \\
\text { Sampling station }\end{array}$} & \multicolumn{6}{|c|}{ May $9^{\text {th }}, 2016$ - Rainy Season } & \multicolumn{6}{|c|}{ October $5^{\text {th }}, 2016$ - Dry Season } \\
\hline & S1 & $\mathbf{S 2}$ & $\mathbf{S 3}$ & S4 & S5 & S6 & S1 & $\mathbf{S 2}$ & $\mathbf{S 3}$ & S4 & S5 & S6 \\
\hline Transparency (m) & 0.19 & 0.41 & 1.38 & 1.35 & 1.41 & 1.35 & 0.68 & 0.73 & 1.41 & 1.60 & 1.30 & 1.52 \\
\hline $\operatorname{Depth}(\mathbf{m})$ & 1.16 & 2.54 & 5.85 & 4.75 & 5.16 & 4.59 & 2.19 & 2.84 & 6.66 & 3.21 & 4.64 & 4.71 \\
\hline Temperature $\left({ }^{\circ} \mathrm{C}\right)$ & 28.41 & 29.04 & 29.37 & 29.67 & 29.70 & 29.87 & 28.85 & 28.91 & 28.21 & 28.17 & 28.19 & 28.30 \\
\hline Salinity $\left(\mathrm{g} \mathrm{kg}^{-1}\right)$ & 3.94 & 13.43 & 27.58 & 28.63 & 28.86 & 29.17 & 18.33 & 29.14 & 33.69 & 34.27 & 34.41 & 34.37 \\
\hline Cond. $\left(\mathrm{mS} \mathrm{cm} \mathbf{c m}^{-1}\right)$ & 7.64 & 24.04 & 46.43 & 48.29 & 48.67 & 49.29 & 31.80 & 48.37 & 54.37 & 55.14 & 55.35 & 55.40 \\
\hline pH & 8.03 & 7.98 & 8.21 & 8.26 & 8.35 & 8.24 & 7.85 & 8.11 & 8.16 & 8.18 & 8.22 & 8.16 \\
\hline DO $\left(\mathrm{mg} \mathrm{L}^{-1}\right)$ & 1.53 & 3.15 & 4.39 & 4.46 & 4.67 & 4.47 & 0.49 & 4.84 & 4.61 & 4.81 & 4.84 & 4.93 \\
\hline $\operatorname{DO}(\%)$ & 28.65 & 72.34 & 95.43 & 99.77 & 102.75 & 98.34 & 10.00 & 104.64 & 101.99 & 106.41 & 107.00 & 109.00 \\
\hline Turbidity (NTU) & 50.00 & 28.00 & 18.00 & 65.00 & 57.00 & 65.00 & 61.00 & 93.00 & 23.00 & 19.00 & 25.00 & 19.00 \\
\hline TSS $\left(\mathbf{m g ~ L} \mathbf{L}^{-1}\right)$ & 59.17 & 74.17 & 54.33 & 123.33 & 118.67 & 112.33 & 82.33 & 156.67 & 48.22 & 60.50 & 46.00 & 50.33 \\
\hline Susp.OM (mg L L-1) & 30.50 & 23.50 & 16.67 & 25.67 & 23.50 & 28.67 & 43.00 & 42.33 & 26.17 & 21.17 & 15.00 & 19.50 \\
\hline Susp. OM (\%) & 52.00 & 33.00 & 31.00 & 21.00 & 20.00 & 26.00 & 52.00 & 27.00 & 52.00 & 36.00 & 33.00 & 39.00 \\
\hline Silicate $\left(\mu \mathrm{mol} \mathrm{L}^{-1}\right)$ & 14.01 & 14.34 & 12.36 & 10.58 & 11.73 & 11.42 & 5.81 & 5.13 & 6.19 & 7.86 & 8.55 & 9.10 \\
\hline Phosphate $\left(\mu \mathrm{mol} \mathbf{L}^{-1}\right)$ & 0.65 & 0.14 & 0.18 & 0.13 & 0.15 & 0.15 & 2.19 & 1.08 & 0.28 & 0.22 & 0.15 & 0.13 \\
\hline OM in sediment $(\%)$ & 3.86 & 2.84 & 1.09 & 4.54 & 4.83 & 4.48 & 0.71 & 1.54 & 0.29 & 11.89 & 2.7 & 1.57 \\
\hline
\end{tabular}



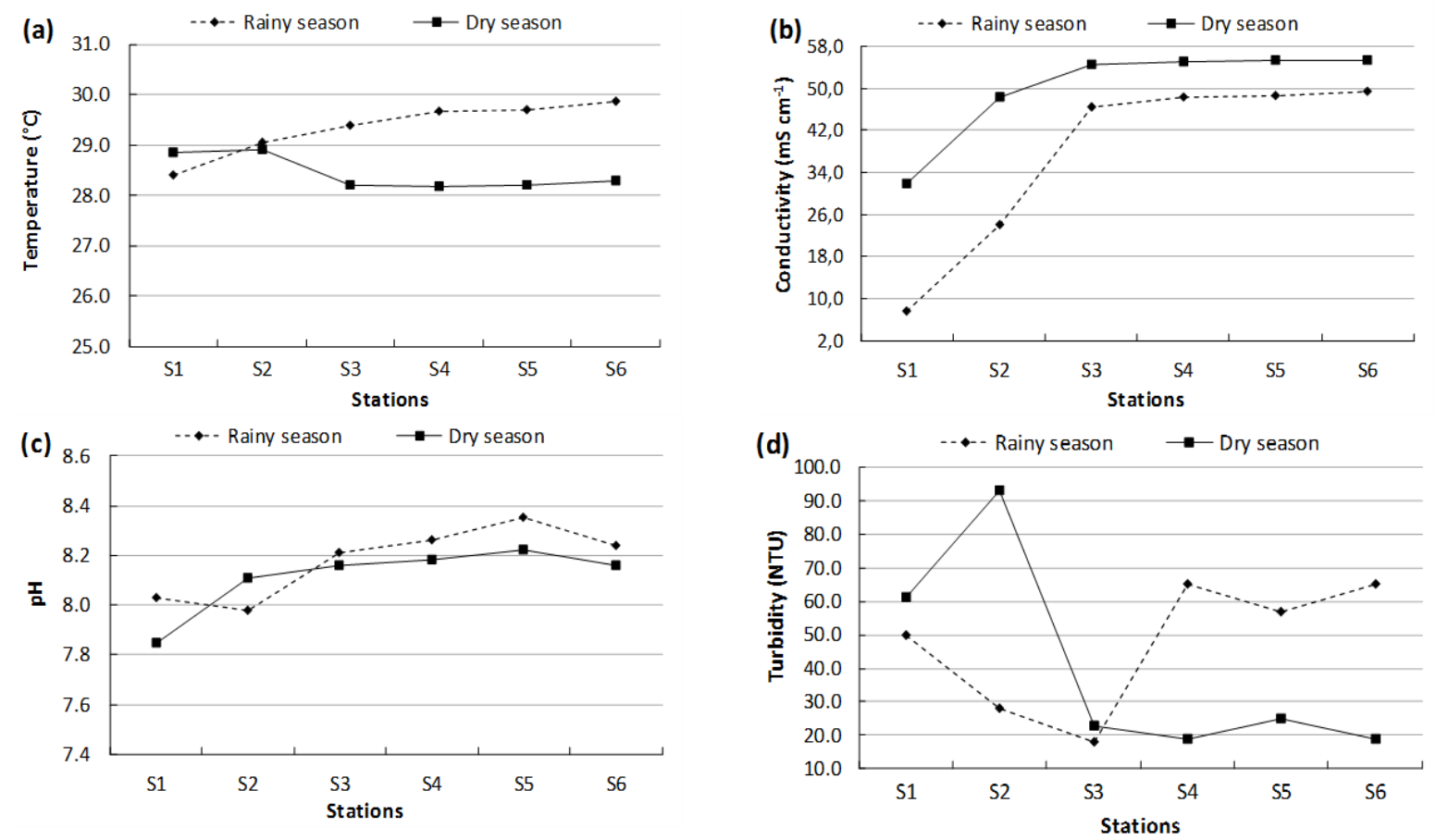

Figure 3. Distribution of physical and chemical variables in Anil River Estuary. (a) Temperature $\left({ }^{\circ} \mathrm{C}\right)$; (b) conductivity $\left(\mathrm{mS} \mathrm{cm}^{-1}\right)$; (c) $\mathrm{pH}$; (d) turbidity (NTU).
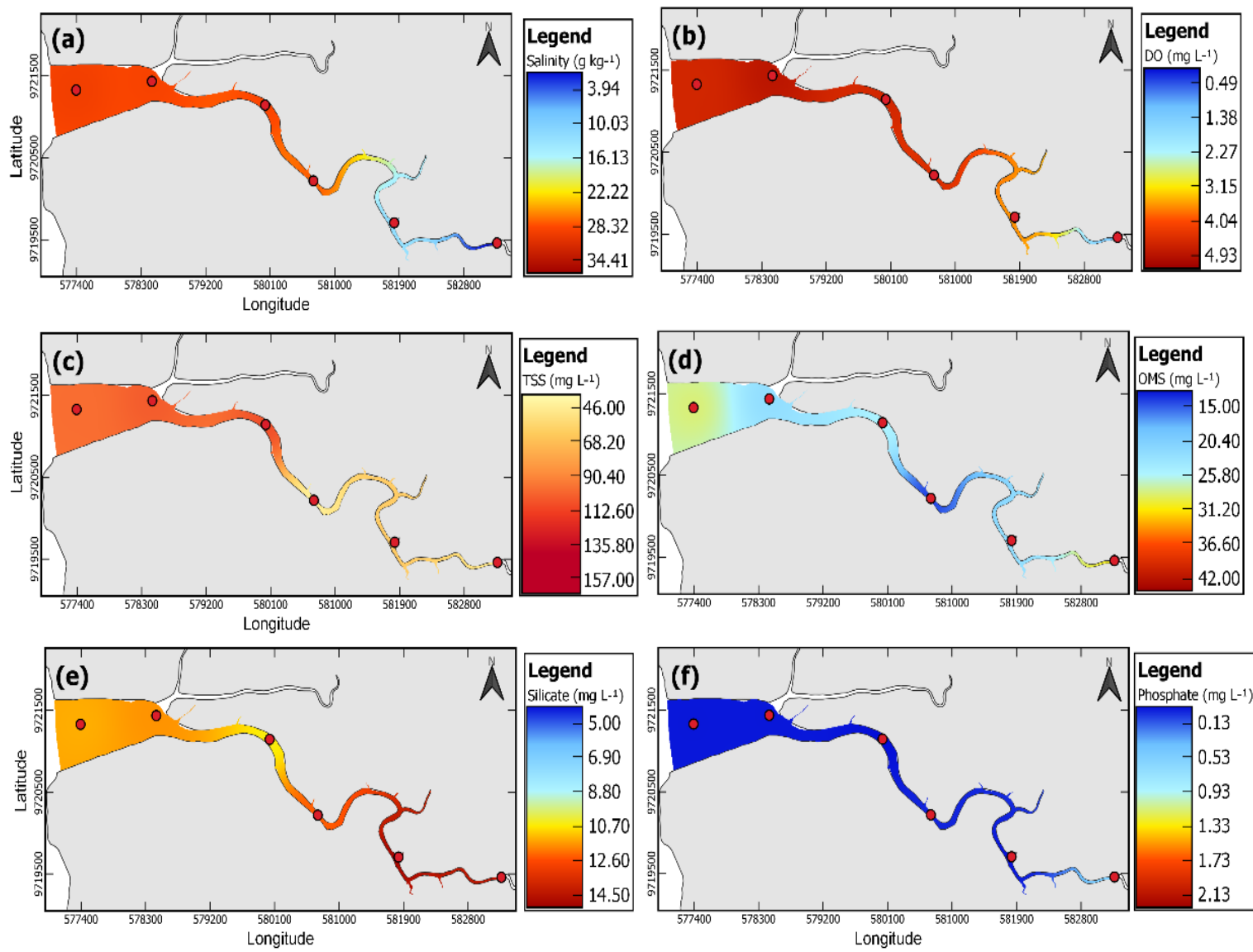

Figure 4. Spatial distribution of hydrological and hydro-chemical variables in surface water of ARE in rainy period (May). (a) Salinity; (b) dissolved oxygen; (c) total suspended solids; (d) suspended organic matter; (e) dissolved silicate; (f) dissolved inorganic phosphate. 

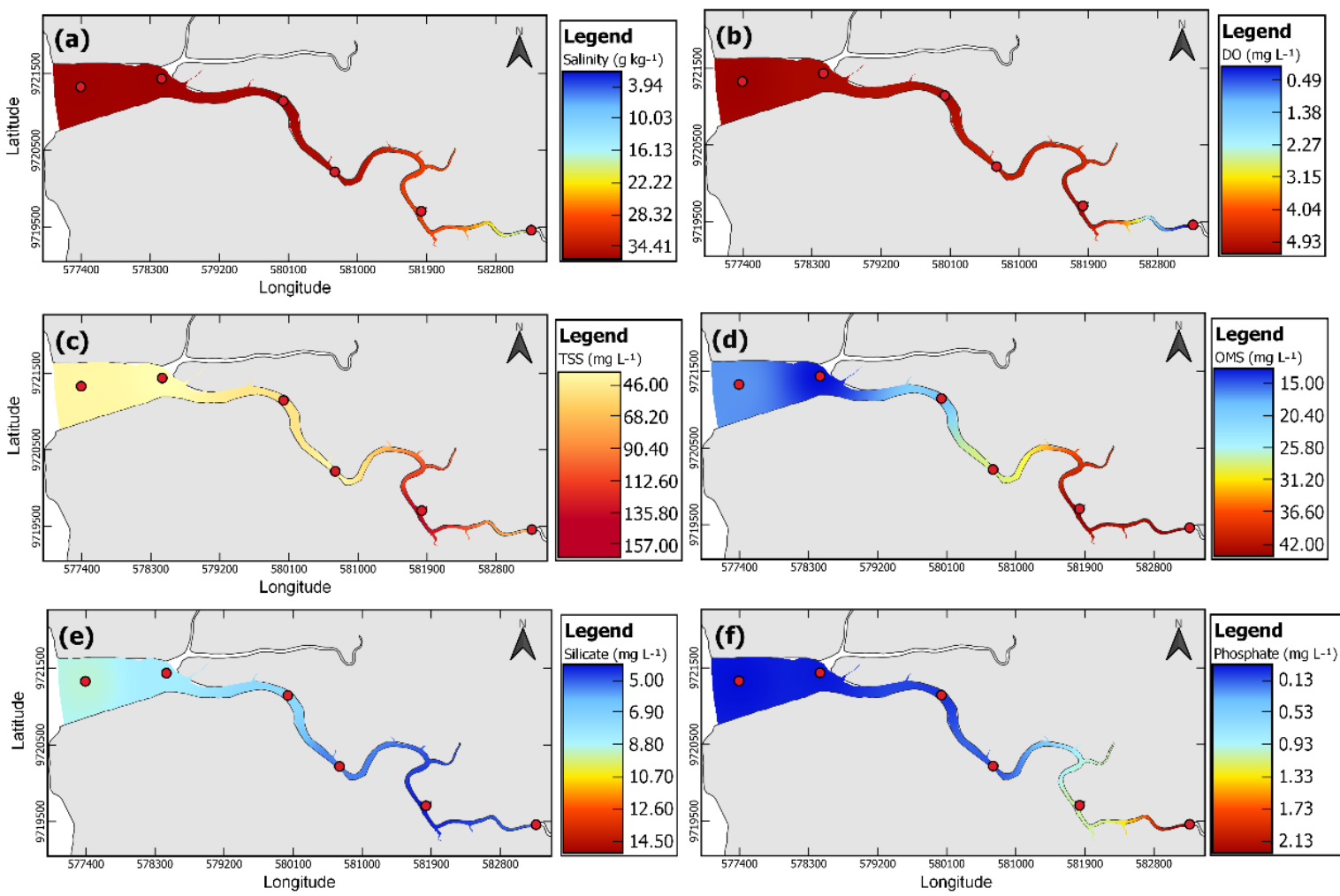

Figure 5. Spatial distribution of hydrological and hydro-chemical variables in surface water of ARE in dry period (October). (a) Salinity; (b) dissolved oxygen; (c) total suspended solids; (d) suspended organic matter; (e) dissolved silicate; (f) dissolved inorganic phosphate.

In the PCA of the rainy period (Figure 6a), the first two components explained $92 \%$ of the total variance in the data: Factor 1 explained $70.5 \%$ and Factor 2 explained 21.5\%. Factor 1 was directly correlated with transparency (transp.), temperature (temp.), salinity (sal.), pH, DO, and TSS, and inversely correlated with silicate and phosphate. Factor 2 was inversely correlated with turbidity and suspended OM.

For the dry period (Figure 6b), the first two axes explained $93.1 \%$ of the total variance in the data: Factor 1 explained $71 \%$ and Factor 2 explained $22.1 \%$. Factor 1 was directly correlated with transparency, salinity, conductivity, $\mathrm{pH}, \mathrm{DO}, \% \mathrm{DO}$, and silicate, and inversely correlated with temperature, turbidity, TSS, suspended OM, and phosphate. Factor 2 was inversely correlated with the percentage of suspended OM.

Water temperature varied little between campaigns (maximum range: $1.7^{\circ} \mathrm{C}$ ). This temperature distribution shows considerable thermal stability in the region, with no large changes in water temperature due to the proximity to the equator. In studies on a macrotidal estuary in the coastal zone of northern Brazil, Monteiro et al. (2015) found temperatures ranging between 28.52 and $29.35^{\circ} \mathrm{C}$ in the transition period between the rainy and dry seasons.

Salinity was predominantly influenced by the inflow and outflow of marine waters in the estuary, with an increasing gradient in the downstream direction. The lowest salinity was found at $\mathrm{S} 1$ in the rainy period due to the increase in river discharge in this period, as reported by Feitosa (1989), which facilitates the dilution of saline ions in the water, reducing salinity in the upstream portions of the estuary. Higher salinity values were found in the dry period, when river discharge is diminished due to the low rainfall, facilitating the penetration of marine waters, evaporation processes also increase the salinity values inside the estuary. In studies conducted in São José Bay in the coastal zone of the state of Maranhão, Serejo et al. (2020) measured salinity ranging from 18.20 to $32.50 \mathrm{~g} \mathrm{~kg}^{-1}$, reporting lower values at low tide and higher values at high tide due to the input of marine waters in the estuary. 


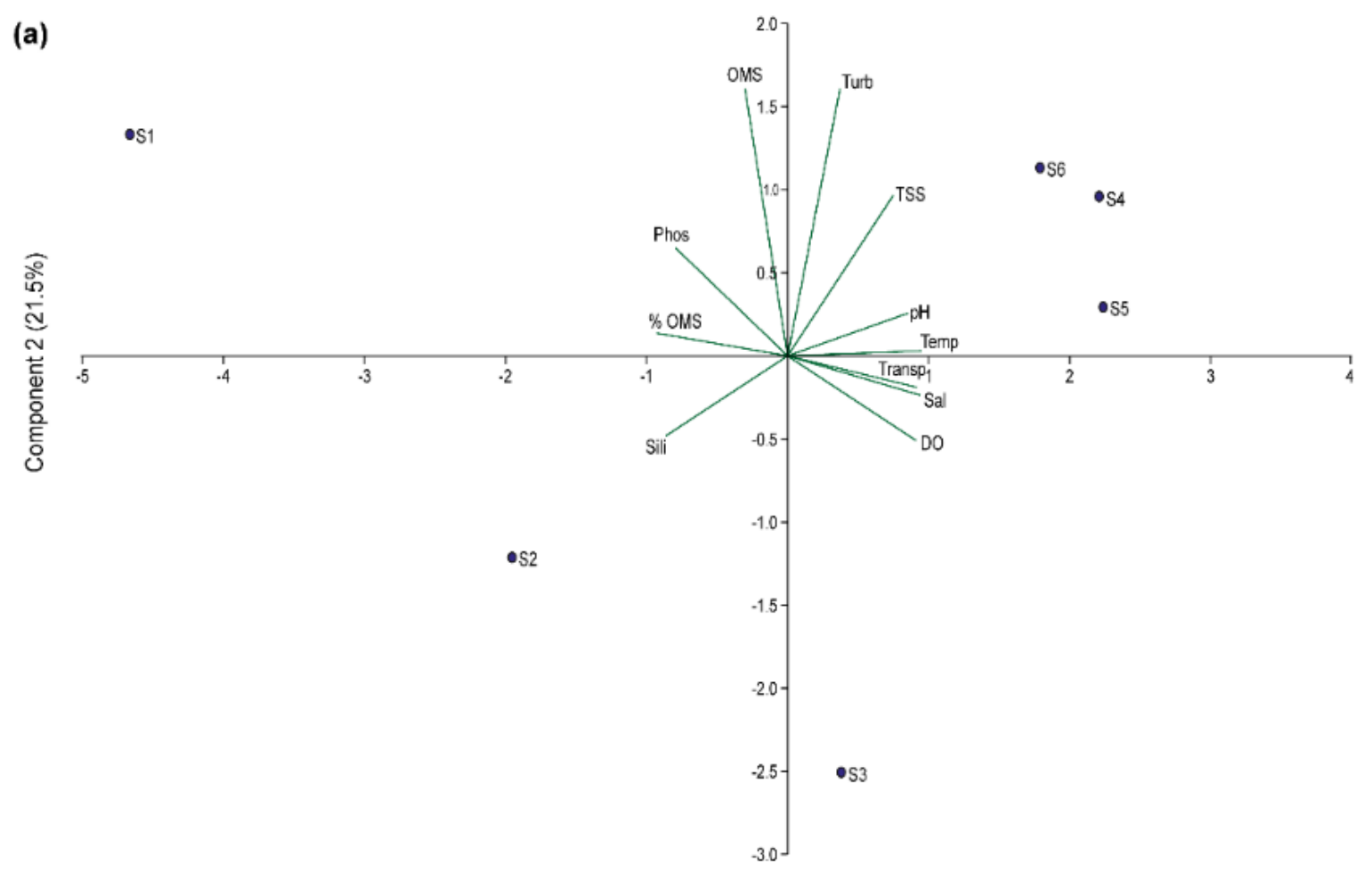

(b)

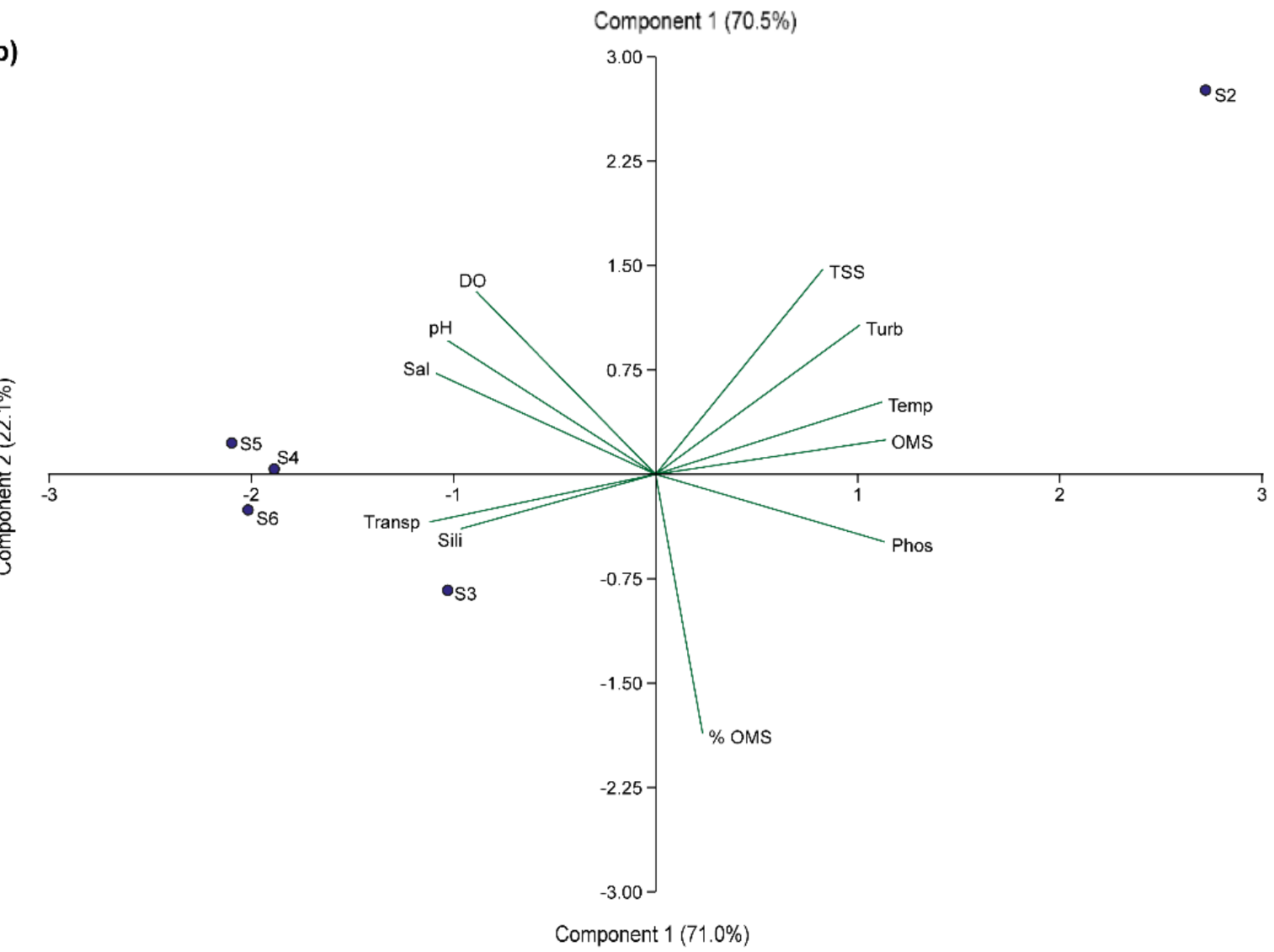

Figure 6. Principal component analysis of hydro chemical variables studied in ARE. (a) rainy period (May); (b) dry period (October).

The growth of the population of the capital of the state of Maranhão in the last 30 years, deforestation, and the irregular occupation of regions near the airport Marechal Cunha Machado in the Tirirical neighborhood resulted in the burying of creeks and swamps that were previously 
considered springs of the Anil River. This led to a $21 \mathrm{~km}$ reduction in the course of the river, diminishing its discharge, which facilitates the entrance of marine waters (Cruz et al., 2020).

The $\mathrm{pH}$ values in the ARE were similar to those normally found at the surface of sea water, with a slight reduction toward the upstream sites (S1 and S2) due to the input of river water, which has more acid pH. Corrêa et al. (2019) recorded pH higher than 8.0 for the coast of the state of Maranhão, attributing these values to the direct influence of macro-tides in the region. The $\mathrm{pH}$ in the ERA can also be altered by factors such as photosynthesis and decomposition of organic matter (Santos et al., 2020).

Higher DO values were found in the dry period, along with an increasing gradient in the downstream direction, indicating a greater marine influence. Marine waters have higher concentrations of DO and the daily variation in tides intensifies the hydrodynamics of the estuary, which facilitates gas exchange with the atmosphere. The ARE was generally characterized as oxygen saturated and its DO values are not limiting for aquatic organisms. The exception was S1, which had the lowest values in both campaigns. This may be associated the continuous input of domestic wastewaters, generating high oxidation of organic matter, which decomposes through a chemical process or microbial action (aerobic bacteria), increasing the oxygen demand and reducing the concentration of dissolved oxygen (Moruzzi and Reali, 2012; Onabule et al., 2020).

Turbidity was greatest downstream in the estuary in the rainy period, which may be related to the greater terrestrial and/or freshwater input due to the contributions of the tributaries of the Anil River and the presence of mangroves near the sampling stations. Lajaunie-Salla et al. (2017) affirms other factors that influence the distribution of turbidity in estuaries are primary productivity, the input of domestic and industrial wastewaters, as well as dissolved organic and particulate matter.

Concentrations of TSS were greater downstream in the rainy period. These values be associated with the deforestation of the mangroves, which are cut and removed for the sale of wood and the fabrication of charcoal on the right margin of the channel. Another determinant of higher TSS concentrations is the turbulence generated by the movement of the tides. Lower concentrations of TSS were found in the dry period, when the freshwater input is diminished and the estuary is influenced more by marine waters, which have lower concentrations of suspended particulate matter. In studies on a macrotidal estuary in the state of Maranhão, Santos et al. (2020) report that the tide plays an important role in the dynamics of the sediments and concentrations of TSS at the surface. The movements of the tide re-suspend fine sediments, increasing concentrations of TSS in the water column as well as controlling the distribution and reworking of bottom sediments.

The concentration of suspended OM in the TSS was slightly higher in the dry period, but with no substantial differences between campaigns. The highest concentrations were found at the upstream stations (S1 and S2), which may be related to the input of domestic and industrial wastewaters, the low transport capacity of the Anil River in the dry period, or even the death of phytoplankton. Studying São Marcos Bay, Corrêa et al. (2019) associated suspended OM values with the greater consumption, decomposition, and transport of organic matter in the rainy period as well as the high evaporation rate in the dry period, with a consequent increase in dissolved organic matter.

Concentrations of inorganic silicate were higher in the rainy period, with a maximum concentration of $14.34 \mu \mathrm{mol} \mathrm{L}{ }^{-1}$. These values are attributed to the process of lixiviation of the crust of the Earth, which intensified in this period, carrying terrigenous materials into the estuary. The high concentrations of silicate in the ARE are the result of the movement of the tides on the mangrove plains, causing the re-suspension of fine sediment.

The intensive hydrodynamics and shallow depth of the estuarine region facilitate the resuspension of bottom sediment in the main channel, which also releases silicate into the water 
column (Rollnic et al., 2018). Domestic and industrial sewage, the removal of mangrove vegetation, and the death of phytoplankton (i.e. degradation of organic matter) are also sources of this nutrient for the aquatic environment.

The low silicate concentrations found in the dry season are associated with the reduced capacity to transport terrigenous material to the water column as well as the reduction in the transport of domestic and industrial effluents. Cavalcanti et al. (2020) found silicate concentrations ranging from 0.95 to $3.61 \mu \mathrm{mol} \mathrm{L}^{-1}$ in the estuary of the Paciência River in São Luís, Maranhão.

Concentrations of inorganic phosphate were mainly influenced by the dynamics of the ARE, which mobilizes the bottom, re-suspending particles in the water column and making phosphorus available. In high concentrations, phosphates lead to the considerable production of organic matter, causing the eutrophication of the environment. The high temperatures in equatorial ecosystems lead to the rapid assimilation and incorporation of phosphate and biomass for the composition of ATP molecules, leading to a very low concentration of this nutrient in the environment.

Physical and chemical variables, such as aluminum, sulfide, organic compounds, carbonates, $\mathrm{pH}$, redox conditions, and the concentration of iron ions, affect the precipitation of phosphate ions in the aquatic environment. In environments with a high $\mathrm{pH}$, calcium can directly influence the adsorption of phosphate to suspended particulate matter. The phosphate ion is precipitated as calcium phosphate or adsorbed to calcium carbonate crystals (Fenzl and Ramos, 1986; Alvarez et al., 2016).

The principal component analysis revealed positive correlations between salinity and transparency, temperature, $\mathrm{pH}, \mathrm{DO}$, and TSS (Factor 1) in the rainy period, showing that the entrance and exiting of marine waters in the ARE exerts a direct influence on these variables, which, in turn, are inversely associated with the distribution of dissolved phosphate and silicate. This suggests the following sources of nutrients: the continent, the Anil River itself (the discharge of which has increased in this period), and/or the input of domestic/industrial wastewaters to the estuary. Factor 2 revealed a negative correlation between suspended OM and turbidity, indicating that these variables are likely influenced by the high content of organic matter from domestic and industrial wastewaters, lixiviation of the continental crust, the resuspension of the bottom sediment due to the intense dynamics as well as the shallow depth of the canal, and/or primary production.

In the PCA of the dry period, Factor 1 revealed significant positive correlations among temperature, turbidity, suspended OM, phosphate, and TSS resulting from the increase in the transport of sedimentary material in the estuary (rainfall, lixiviation, and turbulence), which is typical of waterways (Ludwig and Probst, 1998). The increase in processes of oxidation leads to the release of phosphorus into the water column, demonstrating that the origin of dissolved phosphate in this period is related to the high organic matter content (suspended OM).

The following variables exhibited negative correlations: salinity, transparency, conductivity, $\mathrm{pH}, \mathrm{DO}$, and silicate. This indicates that these variables are governed by marine forces. The influence of salinity on silicate indicates the possibility of organic matter oxidation processes, which remineralize phosphate and silicate, replacing them into the water column in their dissolved form. Factor 2 suggests that TSS was not influenced by other variables and was associated with the re-suspension of the bottom sediment caused by the movement of the tides (intensified by the shallow depth of the estuary), erosion of the banks, or the input of domestic sewage.

\subsection{Grain size characterization}

The sedimentological analyses revealed the mean distribution of grain size among the sampling stations, the average grain size and grading are hydraulically regulated parameters (Saha and Sinha, 2021). In the rainy period, S1 had fine sand, S2 and S3 had medium sand, and

Rev. Ambient. Água vol. 17 n. 1, e2798 - Taubaté 2022 
S4, S5, and S6 had very fine sand. Regarding selection in the same period, S1, S5, S6 were classified as poorly selected, S2 was classified as moderately selected, S3 was classified as well selected, and S4 was classified as very poorly selected. The percentage of clay was generally low, as shown on the cumulative frequency curve (Table 2).

In the dry period, S1, S2, and S3 were classified as having medium sand, S5 and S6 had very fine sand, and S4 was classified as having fine silt, as shown on the cumulative frequency curve. A low percentage of clay was also found in this period (Table 2). Moreover, S1 was classified as moderately selected, S2, S4, and S5 were classified as poorly selected, and S3 and S6 were classified as well selected.

The granulometric distribution in the sediment samples from the main channel of the ARE was heterogeneous, with sand predominantly. Grain size ranged from clay to gravel, with a predominance of sand. The samples in the rainy season ranged from medium to very fine sand. The samples in the dry period ranged from medium sand to fine silt.

Table 2. Percentage of grain size in bottom sediment of Anil River Estuary. Rainy period (1st campaign) and dry period (2nd campaign).

\begin{tabular}{cccccc}
\hline Season & Station & \% Gravel & \% Sand & \% Silt & \% Clay \\
\hline \multirow{4}{*}{ Rainy } & S1 & 0.44 & 82.46 & 16.37 & 0.73 \\
& S2 & 0.68 & 99.32 & 0.00 & 0.00 \\
& S3 & 0.57 & 99.43 & 0.00 & 0.00 \\
& S4 & 0.83 & 57.14 & 39.06 & 2.97 \\
& S5 & 0.03 & 83.08 & 16.80 & 0.10 \\
& S6 & 0.48 & 81.05 & 18.23 & 0.23 \\
\hline \multirow{6}{*}{ Dry } & S1 & 0.00 & 100.00 & 0.00 & 0.00 \\
& S2 & 0.00 & 86.02 & 12.88 & 1.10 \\
& S3 & 0.00 & 100.00 & 0.00 & 0.00 \\
& S4 & 0.00 & 8.68 & 89.68 & 1.64 \\
& S5 & 0.09 & 79.06 & 18.28 & 2.58 \\
& S6 & 0.00 & 84.62 & 14.06 & 1.32 \\
\hline
\end{tabular}

The samples were classified as well selected to very poorly selected in the rainy period and well selected to poorly selected in the dry period due to the presence of mud and sand at some stations, especially S4, confirming heterogeneity. The samples had gravel-sized grains composed of biogenic material of a marine origin (carbonates) and terrestrial origin (leaf debris and other organic compounds), especially in the rainy period.

The percentage of total organic matter in the sediment is shown in Table 1 . The maximum throughout the study was $11.89 \%$ at S4 in the dry period and the minimum was $0.29 \%$ at S3 also in the dry period.

The results of the grain-size analysis were plotted on the Pejrup diagram (Pejrup, 1988) and are shown in Figures $7 \mathrm{a}$ and $7 \mathrm{~b}$ (rainy period and dry period, respectively). The samples were grouped in Area IV, with the classification defined as very high hydrodynamics. Moreover, spatial variations were found as a result of the percentage of sand and silt in the samples. 
(a)

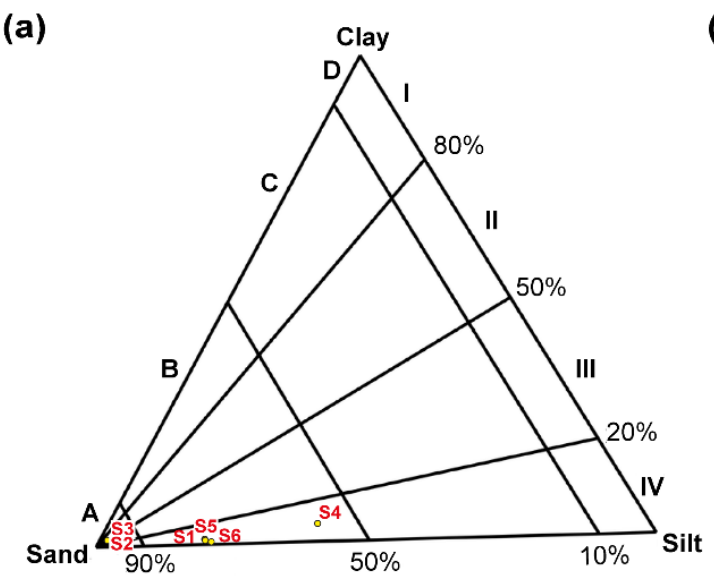

(b)

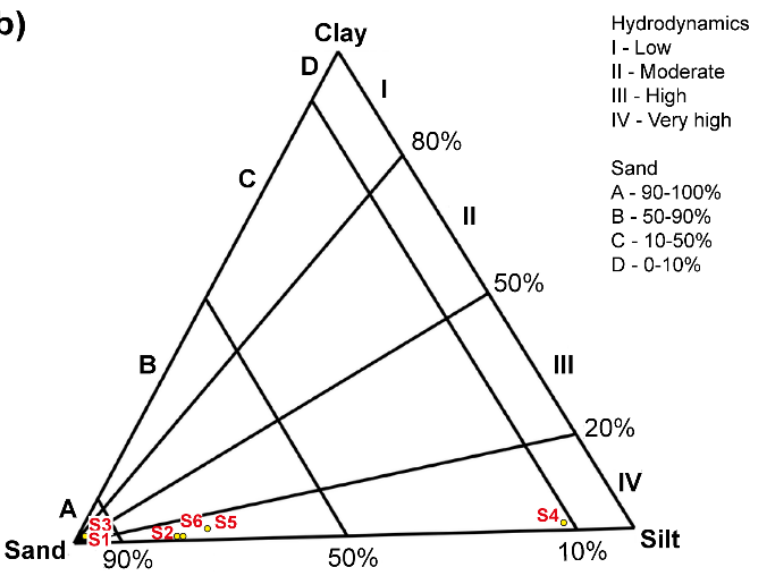

Figure 7. Pejrup diagram of samples collected from Anil River Estuary showing hydrodynamic conditions in the study area. (a) Rainy period (1st campaign); (b) dry period (2nd campaign).

During the rainy period (Figure 7a), the majority of samples belonged to the IV-B Group, corresponding to sediments that contain 50 to $90 \%$ sand. During the dry period (Figure $7 \mathrm{~b}$ ), the majority of samples also belonged to the IV-B Group, whereas one station (S4) was classified in the IV-C Group due to the high percentage of silt (89.68\%) deposited under conditions of low hydrodynamics.

The Pejrup diagrams (Pejrup, 1988) show that the study area is characterized as a region of very high hydrodynamics in both periods. Regions with high hydrodynamic energy, such as estuaries, have a poor selection of grains, impeding the sedimentation of finer particles, which are only deposited in low-energy environments. In estuary and river environments, sediments can flow toward the land or the sea, with changes in magnitude and direction with time due to the position of the estuary, changes in tidal or wave dynamics, freshwater discharge, and meteorological phenomenon (French et al., 2008; Moskalski et al., 2020).

Although the Pejrup diagram (1988) classified the study area as having high hydrodynamics, the granulometric analysis of the region shows the role of the mangroves through the occurrence of silt at some stations in the ARE. The duration between tides in the estuary is not sufficient for the substantial deposition of clay, which requires more than 60 hours (Folk and Ward, 1957). Thus, the granulometry is influenced by the tidal currents, leading to a predominant classification of sand.

The low presence of clay in both periods shows that smaller particles (silt and clay) may comprise the suspended solids in the water, which are remobilized from the bottom sediment of the main channel and the banks due to the intense local hydrodynamics (Brito et al., 2009). The effect of the tide maintains part of the sediment from the mangroves in suspension during the incoming tide, which is deposited in the main channel during the slack water period and can be re-suspended by the subsequent tide (McLachlan et al., 2020).

The samples had a similar behavior in the dry period compared to the rainy period, but S1 and S4 exhibited different distribution between collection periods, changing from fine sand in the rainy period to medium sand in the dry season at $\mathrm{S} 1$ and from very fine sand in the rainy period to fine silt in the dry period at $\mathrm{S} 4$. These changes may be related to the autochthonous sources of the sediment, such as fine sediments originating from the mangroves, the high dynamics of particles deposited on the bottom by tidal currents, the input of domestic wastewaters at particular points, together with the low fluvial dynamics, which are determinants of the deposition of fine sediments. Changes in the granulometry of the samples at the same station may occur due to the erosion of the banks and the degradation of riverine forests combined with the influence of the intense estuarine dynamics.

Serejo et al. (2020) found a predominance of silt and showed that the heterogeneity in the 
granulometric classification and the lack of a spatiotemporal pattern reflected the intense dynamics of a macrotidal estuary located in the Amazon region on the coast of the state of Maranhão.

Total organic matter in the surface sediment of the ARE showed that the sediment of the main channel generally does not lodge large quantities of OM. In the rainy period, the greater river discharge directly influenced the percentage of total OM, exporting this material to downstream stations, which had slightly higher percentages. There is also the contribution of natural sources related to the muddy sediment eroded from the mangroves due to the strong hydrodynamics. As sandy sediments do not aggregate large quantities of OM, the hydrodynamics easily export the concentration of OM with each tide cycle.

The percentages of total OM in the sediment were lower in the dry period compared to the rainy period, as the river discharge diminishes and the Anil River is completely influenced by tidal currents in this period. The only exception was S4, which had high concentrations of OM in the sediments. This is an area of low energy, where fine matter can be deposited and the retention of OM can occur. In the ARE, domestic sewage from populous neighborhoods of the city of São Luís, such as Liberdade, Fé em Deus, Camboa, and Floresta, as well as the nearby hospital discard wastewaters into the estuary channel without previous treatment.

Human activities contribute to changes in the sediment discharges that enter aquatic systems, especially estuaries, which are transitional environments that lodge large quantities of particles of a terrestrial and fluvial origin, altering naturally occurring sedimentary processes and causing a series of impacts on the environment, such as changes in the typology of the bottom sediment, which consequently alter the capacity of the water for retaining chemical elements (Grasso and Le Hir, 2019)

In previous studies in the ARE, Santos et al. (2019) found total OM in the sediment ranging from 0.93 to $16.53 \%$, attributing lower values to the high hydrodynamics of the region and higher values to low hydrodynamics, which favor the deposition of fine sediments, including those rich in OM from the mangroves. The drastic reduction in OM in downstream sediments of the ARE is likely related to the shift in hydrodynamics and deposition processes upon approaching São Marcos Bay.

\section{CONCLUSIONS}

The Anil River Estuary was characterized as a shallow environment (max. $6 \mathrm{~m}$ depth) with low water transparency strongly influenced by the action of the tides, the re-suspension of previously deposited sediments, and the erosion of the banks. As an estuary in an equatorial region, the temperature was high, with slight variations among the sampling points, characterizing a homogenous environment in thermal terms.

Salinity was influenced by seasonality, with lower values in the rainy period and higher values in the dry period. Conductivity was directly proportional to salinity and was also influenced by the flow of marine waters in ARE. The $\mathrm{pH}$ was slightly basic and strongly influenced by the tides.

Lower concentrations of dissolved oxygen were found upstream, caused by the oxidation of the organic loads that enter the system. Downstream, the estuary was well oxygenated due to the dynamic environment with intense gas exchange with the atmosphere and the entrance of marine waters. The concentrations of total suspended solids indicated the influence of the sampling period, with higher values in the rainy period due to the high rainfall and considerable increase in the discharge of the Anil River. Concentrations of suspended organic matter were higher upstream, which may be related to the high organic loads stemming from human activities, together with the re-mobilization of the bottom sediment and erosion of the banks.

The distribution of nutrients in the ARE revealed the occurrence of different sources in the estuary according to semiannual variability. In the rainy period, dissolved silicate was governed 
by terrestrial and fluvial influence and concentrations of dissolved phosphates were influenced by the increase in fluvial transport. Field observations revealed that the discharge of domestic sewage was an important source of this nutrient in both sampling periods. Silicate and phosphate indicated having the same source in the dry period, which may be related to the recycling of organic matter in the estuary, making dissolved nutrients available to the water column.

The main channel of the ARE had a predominantly sandy typology, with granulometry influenced by the high hydrodynamics and semiannual variability in the region. The dynamics of the tide controls the typology and selection of grains in the ARE. With the exception of one sampling station, the sediment had no organic matter retention capacity due to its sandy characteristic and the intense tidal dynamics, which are characteristic of macrotidal estuaries in the Amazon region and hinder the sedimentation of fine particles, maintaining a large part of this material in the water column and facilitating its exportation outside the estuary.

The intense hydrodynamics of the tidal currents (semidiurnal macro-tides), which are characteristic of the region, prevent the permanence of contaminants in the water, making this environment less degraded despite the intense anthropogenic pressures placed on this estuary. The present study contributes to the spatialization of the distribution of physical and chemical variables and the characterization of the bottom sediment of the Anil River Estuary, broadening knowledge on sedimentary typology of an allogenous and autogenous origin. For greater conservation of the area studied, we recommend the treatment of wastewaters, the establishment of rational land use and occupation policies, including the recovery of areas of mangroves that were filled for the building of shanties, and social awareness regarding the impacts generated in recent decades to ensure the stability of the natural balance of these areas.

\section{ACKNOWLEDGEMENTS}

The authors thank the Foundation for Research Support of the State of Maranhão (FAPEMA) for financing the project "Environmental Conditions of the Estuarine Waters of the River Anil (SÃO LUÍS-MA) (APP-UNIVERSAL 00529/15).

\section{REFERENCES}

ALCÂNTARA, E. Mudanças climáticas, incertezas hidrológicas e vazão fluvial: o caso do estuário do Rio Anil. Revista Caminhos de Geografia, v. 5, n. 12, 2004.

ALVAREZ, M. S.; VERA, C. S.; KILADIS, G. N.; LIEBMANN, B. Influence of the Madden Julian Oscillation on precipitation and surface air temperature in South America. Climate Dynamics, v. 46, n. 1-2, p. 245-262, 2016.

AMINOT, A.; CHAUSSEPIED, M. Manuel des analyses chimiques en milieu marin. Paris: CNEXO, 395. p. 1983.

ANDREOLI, R.; KAYANO, M. Tropical Pacific and South Atlantic Effects on Rainfall Variability Over Northeast Brazil. International Journal Of Climatology, v. 26, n. May, p. 1895-1912, 2006.

APHA; AWWA; WEF. Standard Methods for the examination of water and wastewater. 22nd ed. Washington, 2012. 1496 p.

ASP, N. E.; GOMES, V. J. C.; SCHETTINI, C. A. F. et al. Sediment dynamics of a tropical tide-dominated estuary: Turbidity maximum, mangroves and the role of the Amazon River sediment load. Estuarine, Coastal and Shelf Science, v. 214, p. 10-24, 2018. 
BARCELLOS, R. L.; BERBEL, G. B. B.; BRAGA, E. DE S.; FURTADO, V. V. Distribuição e características do fósforo sedimentar no sistema estuarino lagunar de Cananéia-Iguape, Estado de São Paulo, Brasil. Geochimica Brasiliensis, v. 19, n. 1, p. 22-36, 2012.

BRITO, R. N. R. de et al. Fluvial sedimentology associated with the degree of preservation of the riparian vegetation, Urumajó River, PA/Brazil. Acta Amazonica, v. 39, n. 1, p. 173 180, 2009. https://doi.org/10.1590/S0044-59672009000100017

DE CAMARGO, M. G. SysGran: um sistema de código aberto para análises granulométricas do sedimento. Revista Brasileira de Geociências, v. 36, n. 2, p. 371-378, 2006.

CAVALCANTI, L. F.; CUTRIM, M. V. J.; LOURENÇO, C. B. et al. Patterns of phytoplankton structure in response to environmental gradients in a macrotidal estuary of the Equatorial Margin (Atlantic coast, Brazil). Estuarine, Coastal and Shelf Science, v. 245, p. 106969 , 2020 .

CHILDS, C. Interpolating surfaces in ArcGIS spatial analyst. ArcUser, v. 3235, n. 569, p. $32-$ 35, 2004.

CORREAA-MARTINS, F. J. The Neostratotype of Itapecuru Formation (Lower-Middle Albian) and Its Impact for Mesozoic Stratigraphy of Parnaíba Basin. Anais da Academia Brasileira de Ciências, v. 91, 2019.

CORRÊA, M. C.; SEREJO, J. H. F.; RANGEL, T. P. et al. Caracterização biogeoquímica da matéria orgânica em um estuário de macromaré localizado na interface Amazôniasemiárido no nordeste do Brasil. Geochimica Brasiliensis, v. 33, n. 1, p. 107-120, 2019.

COUTINHO, M. D. L.; GAN, M. A.; RAO, V. B. Método objetivo de identificação dos vórtices ciclônicos de altos níveis na região Tropical Sul: validação. Revista Brasileira de Meteorologia, v. 25, n. 3, p. 311-323, 2010.

CRUZ, W. L. DA; RIBEIRO, D. DE Q.; PEREIRA, E. D. Conflitos de Uso e Ocupação em Áreas de Preservação Permanente na Bacia do Rio Anil-São Luís, MA. Revista Geonorte, v. 11, n. 37, p. 229-247, 2020.

DALRYMPLE, R. W. Tidal Depositional Systems. Facies Models: Response to Sea Level Change, p.195-218, 1992.

EL-ROBRINI, M.; ALVES, M. A. M. S.; MARQUES, J. R. V.; EL-ROBRINI, M. H. S.; FEITOSA, A. C.; TAROUCO, J. E. F. et al. Maranhão. In: DIETER M. (Org.). Erosão e Progradação no Litoral Brasileiro. Brasília: Ministério do Meio Ambiente, 2006. p. 87-130.

ESTEVES, F. A. Fundamentos de Limnologia. 3. ed. Rio de Janeiro, 2011.

FEITOSA, A.C. Evolução morfogenética do litoral norte da ilha do Maranhão. 1989. 196 p. Dissertação (Mestrado em Geografia) - Programa de Pós-Graduação em Geografia, Universidade Estadual de São Paulo, São Paulo, 1989.

FENZL, N.; RAMOS, J. F. Introdução à hidrogeoquímica. Belém: Universidade Federal do Pará, 1986.

FOLK, R. L.; WARD, W. C. Brazos River bar [Texas]; a study in the significance of grain size parameters. Journal of Sedimentary Research, v. 27, n. 1, p. 3-26, 1957. 
FRENCH, J. R.; BURNINGHAM, H.; BENSON, T. Tidal and Meteorological Forcing of Suspended Sediment Flux in a Muddy Mesotidal Estuary. Estuaries and Coasts, v. 31, n. 5 , p. $843,2008$.

GOBLER, C. J.; YOUNG, C. S.; GOLESKI, J.; et al. Accidental ecosystem restoration? Assessing the estuary-wide impacts of a new ocean inlet created by Hurricane Sandy. Estuarine, Coastal and Shelf Science, v. 221, p. 132-146, 2019.

GRASSHOFF, K.; KREMLING, K.; EHRHARDT, M. Methods of seawater analysis: contents. New York: Wiley, 1983.

GRASSO, F.; LE HIR, P. Influence of morphological changes on suspended sediment dynamics in a macrotidal estuary: diachronic analysis in the Seine Estuary (France) from 1960 to 2010. Ocean Dynamics, v. 69, n. 1, p. 83-100, 2019.

INMET. Precipitações históricas para São Luís, Maranhão, Brasil. Available at: www.inmet.gov.br. Access: 5 Mar. 2020.

LAJAUNIE-SALLA, K.; WILD-ALLEN, K.; SOTTOLICHIO, A.; THOUVENIN, B.; LITRICO, X.; ABRIL, G. Impact of urban effluents on summer hypoxia in the highly turbid Gironde Estuary, applying a 3D model coupling hydrodynamics, sediment transport and biogeochemical processes. Journal of Marine Systems, v. 174, p. 89-105, 2017.

LUDWIG, W.; PROBST, J. L. River sediment discharge to the oceans: Present-day controls and global budgets. American Journal of Science, v. 298, n. 4, 1998.

MARTINS, A. L. P.; LOPES, M. J. S. Caracterização da população ribeirinha do estuário do Rio Anil (São Luís-MA), com base em aspectos sociais, econômicos e ambientais. Boletim do Laboratório de Hidrobiologia, v. 22, n. 9, p. 9-16, 2009.

MAZDA, Y.; KANAZAWA, N.; WOLANSKI, E. Tidal asymmetry in mangrove creeks. Hydrobiologia, v. 295, n. 1, p. 51-58, 1995.

MCLACHLAN, R. L.; OGSTON, A. S.; ASP, N. E. et al. Estuarine, Coastal and Shelf Science Impacts of tidal-channel connectivity on transport asymmetry and sediment exchange with mangrove forests. Estuarine, Coastal and Shelf Science, v. 233, p. 106524, 2020.

MOLION, L. C. B. Dynamic Climatology of the Amazon region: precipitation mechanisms. Brazilian Journal of Meteorology, v. 2, n. 1, p. 107-117, 1987.

MONTEIRO, S. DE M.; EL-ROBRINI, M. H. S.; ALVES, I. C. C. Dinâmica sazonal de nutrientes em estuário amazônico. Mercator, v. 14, p. 151-162, 2015.

MORUZZI, R. B.; REALI, M. A. P. Oxidação e remoção de ferro e manganês em águas para fins de abastecimento público ou industrial: uma abordagem geral. Revista de Engenharia e Tecnologia, p. 29-43, 2012.

MOSKALSKI, S.; FLOC'H, F.; VERNEY, R. Suspended sediment fluxes in a shallow macrotidal estuary. Marine Geology, v. 419, p. 106050, 2020.

NOBRE, P.; SHUKLA, J. Variations of Sea Surface Temperature, Wind Stress, and Rainfall over the Tropical Atlantic and South America. Journal of Climate, v. 9, p. 2464-2479, 1996. 
ONABULE, O. A.; MITCHELL, S. B.; COUCEIRO, F. The effects of freshwater flow and salinity on turbidity and dissolved oxygen in a shallow Macrotidal estuary: A case study of Portsmouth Harbour. Ocean and Coastal Management, v. 191, p. 105179, 2020.

PEZZI, L. P.; CAVALCANTI, I. F. A. The relative importance of ENSO and tropical Atlantic sea surface temperature anomalies for seasonal precipitation over South America: a numerical study. Climate Dynamics, v. 17, n. 2-3, p. 205-212, 2001.

PEJRUP, M. The triangular diagram used for classification of estuarine sediments: A new approach (pp. 289-300). Dordrecht: Tide-Influenced Sedimentary Environments and Facies, 1988.

POOLE, H. H.; ATKINS, W. R. G. Photo-electric Measurements of Submarine Illumination throughout the Year. Journal of the Marine Biological Association of the United Kingdom, v. 16, n. 1, p. 297-324, 1929.

PRITCHARD, D. W. Estuarine Circulation Pat-terns. Proceedings of the American Society of Civil Engineers, v. 81, n. 717, p. 1-11, 1955.

ROLLNIC, M.; COSTA, M. S.; MEDEIROS, P. R. L.; MONTEIRO, S. M. Tide Influence on Suspended Matter Transport in an Amazonian Estuary. Journal of Coastal Research, v. 85 , n. sp1, p. 121-125, 2018.

SAHA, K.; SINHA, S. Grain size analysis and characterization of sedimentary process in tidal flat of Chandipur region, East Coast of Odisha, India. Marine Geodesy, v. 44, n. 5, p. 485-503, 2021. https://doi.org/10.1080/01490419.2021.1922554

SANTOS, T. T. L.; MARINS, R. V.; DIAS, F. J. DA S. Carbon influence on metal distribution in sediment of Amazonian macrotidal estuaries of northeastern Brazil. Environmental Monitoring and Assessment, p. 1-16, 2019.

SANTOS, T. T. L.; SEREJO, J. H. F.; LIMA, H. P.; ESCHRIQUE, S. A. Dissolved Nutrient Fluxes in Macrotidal Estuary in the Amazonian Region, Brazil. Tropical Oceanography, v. 48, n. 1, p. 1-19, 2020.

SEREJO, J. H.; SANTOS, T. T.; LIMA, H. P.; AZEVEDO, I. H.; DOS SANTOS, V. H.; ESCHRIQUE, S. A. Fortnightly variability of total suspended solids and bottom sediments in a macrotidal estuarine complex on the Brazilian northern coast. Journal of Sedimentary Environments, p. 101-115, 2020.

SERRA, C. L. M.; CAVAlCANTE, P. R. S.; ALVES, L. M. C.; NASCIMENTO, A. R.; DINIZ, S. C. C. DE S. DE. Avaliação de parâmetros físicos e químicos e pesquisa de Vibrio parahaemolyticus em águas do estuário do rio Anil (São Luís, Estado do Maranhão). Acta Scientiarum. Biological Sciences, v. 25, p. 261-266, 2003.

STRICKLAND, J. D.; PARSONS., T. R. A practical handbook for seawater analysis. 2nd ed. Ottawa: Fischeries Research Board of Canada, 1972.

VERONEZ, P.; BASTOS, A. C.; DA SILVA QUARESMA, V. Morfologia e distribuição sedimentar em um sistema estuarino tropical: Baía de Vitória, ES. Revista Brasileira de Geofisica, v. 27, n. 4, 2009.

WATSON, D. F.; PHILIP, G. M. A refinement of inverse distance weighted interpolation. Geoprocessing, v. 2, n. 4, p. 315-327, 1985. 
WENTWORTH, C. K. A scale of grade and class terms for clastic sediments. The Journal of Geology, v. 30, n. 5, p. 377-392, 1922.

WOLANSKI, E.; ELLIOTT, M. Estuarine Ecohydrology: an introduction. 2nd ed. New York: Elsevier, 2015.

WETZEL, R. G. Limnology. London: W. B. Sounders, 1975. 